\title{
Phytochemical Study, Antioxidant and Cytotoxic Activities of Brassica rapa L. leaves Extract and Its Silver Nanoparticles
}

\author{
R. E. Shafek ${ }^{1 *}$, H. N. Michael ${ }^{1}$, A. Z. Sayed ${ }^{2}$, A. G. Ibrahim² ${ }^{2}$ A.M. Al-sayed ${ }^{1}$ \\ ${ }^{1}$ Chemistry of Tanning Materials and Leather Technology Department, National \\ Research Centre, Dokki, Cairo, Egypt. \\ ${ }^{2}$ ChemistryDepartment, Faculty of Science, Al-Azhar University, 11884, Nasr City, \\ Cairo, Egypt.
}

\begin{abstract}
C HEMICAL constituents, antioxidant activities and cytotoxic effects of the $70 \%$ aqueous ethanolic extract of Brassica rapa L.(six fractions $\mathrm{F}_{1-6}$ ) of Brassica rapa extract (BRE) were investigated. Its chromatographic, chemical and spectral analysis detected the existence of a new natural isorhamnetin glycoside namely; isorhamnetin 3-O- $\beta$-D-glucopyranosyl $\left(1^{\prime \prime \prime} \rightarrow 2^{\prime \prime}\right)$ $\alpha$-L-rhamnopyranosyl $\left(1^{\prime \prime} \rightarrow 2\right.$ ") $-\beta$-D-glucopyranoside $\left(\mathrm{L}_{2}\right)$ together with fifteen known flavonoid compounds; five of the type kaempferol glycosides, four of quercetin glycosides, three of isorhamnetin glycosides and three aglycones. Silver metal nanoparticles of the ethanolic extract were also prepared which gave nanoparticles less than $20 \mathrm{~nm}$. The two extracts (ethanolic extract and its nanoparticles) were evaluated for their potential cytotoxicity and as an antioxidant which showed that, the highest antioxidant extract was nano silver Brassica rapa extract (NBRE). followed by Brassica rapa extract (BRE). The Brassica rapa extract (BRE) and its nano silver Brassica rapa extract (NBRE) were evaluated against HELA cells (human Cervical cancer cell line) and M-NFS-60 cells (human Mouse Myelogenous Leukemia carcinoma) with Doxorubicin as standard drug which NBRE (nano silver Brassica rapa extract) gave high activity for both two cell line.
\end{abstract}

Keywords: Brassica rapa L., Phytochemical, Silver nanoparticles, Antioxidant, Cytotoxic activity.

\section{Introduction}

The Brassicaceae family (=Cruciferae) encompasses 350 genera and about 3,500 species, and several genera like Camelina, Crambe, Sinapis, Thlaspi and Brassica. The genus Brassica is the most important one in the family as it includes some crops and species of great worldwide economic importance such as Brassica oleracea L., Brassica napus L. and Brassica rapa L. The same species can be used for several purposes according to different forms or types. Brassicaceae vegetables are looked upon an important part of the human diet all over the world, consumed by people worldwide and considered vital food crops in China, Japan, India, and European countries. The main vegetable species is Brassica oleracea, which involves vegetable and forage forms, such as kale, cabbage, broccoli, brussels sprouts, cauliflower and others; Brassica Rapa encompasses vegetable forms, such as turnip, Chinese cabbage and pakchoi, as well as forage and oilseed types [1].
Within it Brassica rapa L (BR). which is known in Egypt as Left, and it used as an edible vegetable. It is famously used in the Unani and Arab folk medicine due to its effect in treatment of stomach ache, cholecystitis, constipation, cholecystolithiasis moreover the hepatic disorders[2]. The antimicrobial activities of Brassica rapa L (BR) roots have long been used in traditional medicine as a good treatment of flue. Brassica rapa L (BR) is known as a weed [2]. In folk medicine, the seed powdered commonly known for treatment of mammary cancer, also a salve extracted from roots may benefit in treating skin tumor [3]. Brassica rapa L (BR) edible parts are used as a raw, boiled and/or fermented vegetable all over the world. They possess many organic compounds which have biological activity e.g glucosinolates, phenylpropanoids, flavonoids, phenolics and organic acids [4]. Its antibacterial properties were previously proved [3]. The methanolic extracts of Micrococcus species 
showed the highest antibacterial activity while mold was resistant to this extract. Other alcoholic extracts also showed such higher activity. While other significant biological properties of Brassica rapa L. involved liver protection [5]. Moreover its ethanolic extract exhibited anti diabetic property in all oxidized diabetic rats [6]. Some studies showed that the ethanolic extract of its roots has potential antioxidant ability to scavenge free radicals, nitrite radical and inhibited the lipid peroxidation $[7,8]$. Previous studies showed that many phenolic and flavonoid compounds were isolated from family Brassicaceae $[1,9,10]$. In this communication, phytochemical studies of the ethanolic extract of Brassica rapa $\mathrm{L}$ (BRE) revealed the presence of 16 flavonoid compounds namely:- kaempferol3-O-Sophoroside -7-O- $\beta$-D-glucoside $\left(\mathrm{L}_{1}\right)$, isorhamnetin 3-O- $\beta$ - D-glucopyranosyl $\left(1^{\prime \prime \prime} \rightarrow 2^{\prime \prime \prime}\right)-\alpha-\mathrm{L}$ rhamnopyranosyl $\left(1^{\prime \prime \prime} \rightarrow 2^{\prime \prime}\right)-\beta$ - D-glucopyranoside $\left(\mathrm{L}_{2}\right)$ (the new compound), quercetin 3,7-O - $\beta$-Ddiglucopyranoside $\left(\mathrm{L}_{3}\right)$, kaempferol-3,7-O- $\beta$ D-diglucopyranoside $\left(\mathrm{L}_{4}\right)$, kaempferol-3-OSophoroside $\left(\mathrm{L}_{5}\right)$, quercetin- 3-O-Sophoroside $\left(\mathrm{L}_{6}\right)$ isorhamnetin-3-O- $\alpha$-L-rhamnopyranosyl$(1 \rightarrow 6)-\beta$-D- glucopyranoside $\left(\mathrm{L}_{7}\right)$, isorhamnetin3-O- $\alpha$ - L-rhamnopyranosyl- $\quad(1 \rightarrow 2) \quad-\beta$ D- glucopyranoside $\mathrm{L}_{8}$ ), quercetin $3-\mathrm{O}-\beta-$ D- glucopyranoside $\left(\mathrm{L}_{9}\right)$, quercetin $7-\mathrm{O}-\beta$ D- glucopyranoside $\left(\mathrm{L}_{10}\right)$, isorhamnetin-3-O$\beta$-D- glucopyranoside $\left(\mathrm{L}_{11}\right)$, kaempferol 3-O- $\beta$ D-glucopyranoside $\left(\mathrm{L}_{12}\right)$, kaempferol 7-O- $\beta$ D-glucopyranoside $\left(\mathrm{L}_{13}\right)$, kaempferol $\left(\mathrm{L}_{14}\right)$, quercetin $\left(\mathrm{L}_{15}\right)$ and isorhamnetin $\left(\mathrm{L}_{16}\right)$. Besides the investigation of the antioxidant and cytotoxic activities of Brassica rapa L extract (BRE) and its silver nanoparticles extract (NBRE).

\section{Materials and Methods}

Plant material

The leaves of Brassica rapa L. were collected from Egyptian market in February 2013 and identified by Dr. Mohamed Elgebally, Consultant of plant taxonomy at ministry of agriculture.

\section{Chemicals and instruments}

${ }^{1} \mathrm{H}-\mathrm{NMR}$ spectra were measured by Jeol EX-500 NMR spectrometer, $500 \mathrm{MHz} .{ }^{1} \mathrm{H}$ chemical shifts were measured relative to TMS and ${ }^{13} \mathrm{C}$-NMR chemical shifts to
DMSO- $\mathrm{d}_{6}$ and converted to TMS scale by adding 39.5. ESI-MS spectra were measured on SSQ Finnigan MAT 4600 quadrupole mass spectrometer (Institute für chemie, Humboldt universität, Berlin). UV spectra were measured on Shimadzu spectrophotometer model UV240; Column chromatography (CC): was performed using Polyamide 6S (Riedel, De Häen) and Sephadex LH-20 (Pharmacia); paper chromatography (PC): Whatman No. 1 and preparative (PPC) on 3 MM paper using the following solvent systems: (1) BAW ( $n-\mathrm{BuOH} / \mathrm{AcOH} / \mathrm{H}_{2} \mathrm{O}$, 4:1:5); (2) $\mathrm{H}_{2} \mathrm{O}$; (3) 15\% AcOH(AcOH: $\mathrm{H}_{2} \mathrm{O}$ 15:85), (4) Forestall (AcOH: Conc. $\mathrm{HCl}: \mathrm{H}_{2} \mathrm{O}: 30: 3: 10$ ) and were visualized under UV light using aluminium chloride $\left(\mathrm{AlCl}_{3}\right)$ and Naturstoff reagent $\mathrm{A}$ (Diphenyl boric acid- $\beta$-amino ethyl ester (NA) as spraying reagents. Aniline hydrogen phthalate was used as specific reagent for sugar analysis.

\section{Extraction and fractionation}

The fresh leaves $(3 \mathrm{Kg}$ ) were cut into small pieces then extracted with $70 \%$ ethanol till complete exhaustion at temperature $60^{\circ} \mathrm{c}$.The collected ethanolic extract was firstly filtered then concentrated under vacuum (100 gm) and examined by both $\mathrm{FeCl}_{3}$ and Shinoda'stest which indicate the presence of compounds of strong phenolic and flavonoid nature. It is TDPC. using the solvent systems BAW. and $15 \% \mathrm{AcOH}$, respectively, revealed the presence of many components of flavonoids nature. Polyamide (750 gm) column chromatography of the ethanolic extract, using water as eluent, followed by increasing concentration of the ethyl alcohol till $100 \%$ led to desorption of six fractions $\left(\mathrm{F}_{1-6}\right)$.

Two compounds $\mathrm{L}_{1}$ and the new compound $\mathrm{L}_{2}$ were isolated from $\mathrm{F}_{2}$ which eluted with $20 \%$ ethanol, four compounds were isolated from $\mathrm{F}_{3}\left(\mathrm{~L}_{3}-\mathrm{L}_{6}\right)$; eluted with $40 \%$ ethanol. While $\mathrm{F}_{4}$ (eluted with $60 \%$ ethanol) was found to contain two compounds $\mathrm{L}_{7}$ and $\mathrm{L}_{8}, \mathrm{~F}_{5}$ (eluted with $80 \%$ ethanol) which gave $\left(\mathrm{L}_{9}, \mathrm{~L}_{10}, \mathrm{~L}_{11}, \mathrm{~L}_{12}, \mathrm{~L}_{13}\right)$. The last compounds were isolated from $\mathrm{F}_{6}$ were aglycone $\left(\mathrm{L}_{14}, \mathrm{~L}_{15}\right.$ and $\left.\mathrm{L}_{16}\right)$. 




Fig .1. Structure of isolated new conpound (L2).

\section{Preparation of silver nanoparticles}

Silver nitrate was purchased from National Research Centre and used as received, distilled deionized water used in the reactions. The plant was collected and washed with sterile distilled water, then extracted with $70 \%$ alcohol in the conical flask at $50^{\circ} \mathrm{C}$. The mixture was then filtered and dried under vacuum. To obtain the extract of Brassica rapa, $5 \mathrm{~g}$ of extract was added to $100 \mathrm{~mL}$ of deionized water and incubated with shaking in dark conditions at $25^{\circ} \mathrm{C}$ for 3 hours. The obtained mixture was filtered and purified by centrifugation at $6000 \mathrm{rpm}$ for $20 \mathrm{~min}$. These solutions were stored at $4^{0} \mathrm{C}$ and used within 1 week. For preparation of silver nanoparticles, $10 \mathrm{~mL}$ of the prepared extract was typically added to $100 \mathrm{~mL}$ of $3 \mathrm{mM}$ aqueous silver nitrate solution and incubated in a rotary shaker for 2 h. Plant extract at $20 \%$ was the best reducing agent in terms of the synthesis rate of conversion to silver nanoparticles. The silver nanoparticle solution thus obtained was purified by repeated centrifugation at $12,000 \mathrm{rpm}$ for $20 \mathrm{~min}$. After freeze-drying of the purified silver nanoparticles, the structure, composition, and average size of the synthesized silver nano particles were analyzed by transition electonmicroscopy (TEM), Fourier Transform Infrared Spectroscopy (FTIR) spectroscopy, Ultraviolet-visible spectroscopy (UV spectroscopy)[11] .

\section{Evaluation of antioxidant activity}

DPPH radical scavenging assay

The antioxidant capacity of the (ethanolic and nano particles extract) of Brassica rapa was measured using a DPPH method described by using the free radical 2,2-diphyenylpicrylhydrazyl (DPPH), with some minor revisions. Aliquots $(0.1 \mathrm{~mL})$ of diluted extracts in methanol were added to $1 \mathrm{~mL}$ of DPPH solution and the absorbance of the DPPH solution was determined at $517 \mathrm{~nm}$ after 30 min of incubation at room temperature. Appropriate blanks (methanol) and standard (Trolox solution in methanol) were used to compare the antioxidant capacity of BRE. All measurements were done in triplicate. The radical-scavenging activity (RSA) was calculated as a percentage of DPPH discoloration using the equation[12] :

$$
\% \mathbf{R S A}=\left(\mathrm{A}_{\text {blank }}-\mathbf{A}_{\text {sample }} / \mathbf{A}_{\text {blank }}\right) \times 100
$$

Evaluation of potential cytotoxicity

Mammalian cell lines:

HELA cells (human Cervical cancer cell line), M-NFS-60 cells (human Mouse Myelogenous Leukemia carcinoma) were obtained from VACSERA Tissue Culture Unit.

\section{Chemicals Used}

Dimethyl sulfoxide (DMSO), crystal violet and trypan blue dye were purchased from Sigma (St.Louis,Mo.,USA). Fetal Bovine serum, DMEM, RPMI-1640, HEPES buffer solution, L-glutamine, gentamycin and $0.25 \%$ TrypsinEDTA were purchased from Lonza.

Crystal violet stain (1\%)

It composed of $0.5 \%(\mathrm{w} / \mathrm{v})$ crystal violet and Egypt.J.Chem. 61, No.2 (2018) 
$50 \%$ methanol then made up to volume with $\mathrm{ddH}_{2} \mathrm{O}$ and filtered through a Whatman No.1 filter paper.

\section{Cell line Propagation}

The cells were propagated in Dulbecco's modified Eagle's medium (DMEM) supplemented with $10 \%$ heat-inactivated fetal bovine serum, $1 \%$ L-glutamine, HEPES buffer and $50 \mu \mathrm{g} / \mathrm{ml}$ gentamycin. All cells were maintained at $37^{\circ} \mathrm{C}$ in a humidified atmosphere with $5 \% \mathrm{CO}_{2}$ and were subcultured two times a week.

\section{Cytotoxicity evaluation using viability assay}

For cytotoxicity assay, the cells were seeded in 96-well plate at a cell concentration of $1 \times 10^{4}$ cells per well in $100 \mu 1$ of growth medium. Fresh medium containing different concentrations of the test sample was added after $24 \mathrm{~h}$ of seeding. Serial two-fold dilutions of the tested chemical compound were added to confluent cell monolayers dispensed into 96-well, flat-bottomed microtiter plates (Falcon, NJ, USA) using a multichannel pipette. The microtiter plates were incubated at $37^{\circ} \mathrm{C}$ in a humidified incubator with $5 \% \mathrm{CO}_{2}$ for a period of $48 \mathrm{~h}$. Three wells were used for each concentration of the test sample. Control cells were incubated without test sample and with or without DMSO. The little percentage of DMSO present in the wells (maximal $0.1 \%$ ) was found not to affect the experiment. After incubation of the cells for at $37^{\circ} \mathrm{C}$, various concentrations of sample were added, and the incubation was continued for $24 \mathrm{~h}$ and viable cells yield was determined by a colorimetric method.

In brief, after the end of the incubation period, the media were aspirated and the crystal violet solution $(1 \%)$ was added to each well for at least 30 minutes. The stain was removed and the plates were rinsed using tap water until all excess stain is removed. Glacial acetic acid (30\%) was then added to all wells and mixed thoroughly, and then the absorbance of the plates was measured after gently shaken on Microplate reader (TECAN, Inc.), using a test wavelength of $490 \mathrm{~nm}$. All results were corrected for background absorbance detected in wells without added stain. Treated samples were compared with the cell control in the absence of the tested compounds. All experiments were carried out in triplicate. The cell cytotoxic effect of each tested compound was calculated. The optical density was measured with the microplate reader (SunRise, TECAN, Inc, USA) to determine the number of viable cells and the percentage of viability was calculated as [1-(ODt/ ODc)] $\times 100 \%$ where ODt is the mean optical density of wells treated with the tested sample and ODc is the mean optical density of untreated cells. The relation between surviving cells and drug concentration isplotted to get the survival curve of each tumor cell line after treatment with the specified compound. The 50\% inhibitory concentration $\left(\mathrm{IC}_{50}\right)$, the concentration required to cause toxic effects in $50 \%$ of intact cells, was estimated from graphic plots of the dose response curve for each conc. using Graph pad Prism software (San Diego, CA. USA) [13,14].

Isorhamnetin 3-O- $\beta$-Dglucopyranosyl $\left(1^{\prime \prime \prime \prime} \rightarrow 2^{\prime \prime \prime}\right)-\alpha-L$ rhamnopyranosyl $\left(1^{\prime \prime \prime} \rightarrow 2^{\prime \prime}\right)-\beta$ Dglucopyranoside $\left(L_{2}\right)$

$\mathrm{R}_{\mathrm{f}}$-values $(\times 100) 40$ in BAW, 68 in $15 \%$ $\mathrm{AcOH}, 75$ in $\mathrm{H}_{2} \mathrm{O}$ : UV Spectral Data $\lambda_{\text {max }}(\mathrm{nm})$ $\mathrm{MeOH}: 255$, 354 ;+NaOMe: 272 , $323 \mathrm{sh}, 414$ ;+NaOAc (b) : $273,325 \mathrm{sh}, 367,492 ;+\mathrm{H}_{3} \mathrm{BO}_{3}$ : $255,356 \mathrm{sh}, 470 ;+\mathrm{AlCl}_{3}: 267,301 \mathrm{sh}, 399$ ;+ $\mathrm{HCl}$ : 267 , 357,396 ; ${ }^{1} \mathrm{H}-\mathrm{NMR}$ spectral data(DMSO- $d_{6}$ ): Aglycone moiety : 7.90 ( d, $J=$ $\left.1.8 \mathrm{~Hz}, \mathrm{H}-2^{\prime}\right), 7.45$ ( dd, $\left.J=8.0,1.8 \mathrm{~Hz}, \mathrm{H}-6^{\prime}\right), 6.87$ ( d, $\left.J=8.0 \mathrm{~Hz}, \mathrm{H}-5^{\prime}\right), 6.38(\mathrm{~d}, J=1.8 \mathrm{~Hz}, \mathrm{H}-8)$, $6.15(\mathrm{~d}, J=1.8 \mathrm{~Hz}, \mathrm{H}-6), 3.8\left(3 \mathrm{H}, \mathrm{s}, \mathrm{OCH}_{3}\right)$.

Sugar moiety : 5.54 ( d, $J=7.45 \mathrm{~Hz}$, glc-H-1" ), $5.38\left(\mathrm{~d}, \mathrm{~J}=2.0 \mathrm{~Hz}, \mathrm{H}-1^{\prime \prime}\right.$ of anomeric proton of rhamnose), 4.98 ( d, $J=7.45 \mathrm{~Hz}$, glc-H-1"' $), 0.87$ (d,J=6.3 Hz , rhamnosyl methyl group), 3.073.53 (m, sugar protons). ${ }^{13} \mathrm{C}-\mathrm{NMR}$ spectral data $\left(\mathrm{DMSO}-d_{6}\right): 156.2(\mathrm{C}-2), 133.3(\mathrm{C}-3), 177.0(\mathrm{C}-4)$, 161.0(C-5), 98.8(C-6), 165.0(C-7), 93.7(C8), 155.7 ( C-9),103.5 (C-10),120.9(C-1'), 115.0(C-2'), 149.2(C-3'), 146.7 (C-4'), 113.3 (C-5'), 121.6(C-6'), $55.5\left(\mathrm{OCH}_{3}\right)$.Sugar moieties: Glucose sugar at $\delta(\mathrm{ppm})$ : $98.2\left(\mathrm{C}-1^{\prime \prime}\right), 77.5\left(\mathrm{C}-2^{\prime \prime}\right), 77.2(\mathrm{C}-$ 3"), $76.9\left(\mathrm{C}-5^{\prime \prime}\right), 71.5$ (C-4"),60.3(C-6"); Rhamnose sugar at : $\delta$ (ppm): $100.6\left(\mathrm{C}-1^{\prime \prime}\right), 81.8\left(\mathrm{C}-2^{\prime \prime}\right)$, 69.9 (C-3"'),72.1 (C-4"), 68.1 (C-5"), 17.6(C-6") methyl group of Rhamnose; Glucose sugar at $\delta$ (ppm): 104.3 (C-1"'”), 74.0 (C-2'"'), 76.3 (C-3'"'), 70.5 (C-4"'), $74.0\left(\mathrm{C}-5^{\prime \prime \prime \prime}\right), 62.4\left(\mathrm{C}-6^{\prime \prime \prime}\right)$. Negative ESIMS; $m / z 785[M-H]^{-}$.

\section{Results and Discussion}

Investigation of the polyphenolic constituents of Brassica rapa extract.

The present study investigated the polyphenolic constituents of (BRE) which led to the isolation of sixteen flavonoid compounds $\left(\mathrm{L}_{1}-\mathrm{L}_{16}\right)$ including one new $\left(\mathrm{L}_{2}\right)$, which was separated in pure form 
after successive chromatographic isolation using polyamide $6 \mathrm{~S}$ column for fractionation and PPC or Sephadex LH-20 column for isolation or purification.

The glycoside $\left(\mathrm{L}_{2}\right)$ is seen on paper chromatograms as brown spot under UV light and changed to yellow colour on exposing to ammonia vapours. Its $\mathrm{R}_{\mathrm{f}}$ - values, colour reactions and UV spectral data were in accordance with a 3-substituted isorhamnetin[15]; where the addition of sodium methoxide led to a bathochromic shift (58 nm) in a band (I) with an increase in its intensity with the appearance of a shoulder at $(323 \mathrm{~nm})$ i.e. position 3 was occupied while position 7 was free. This was proved by the bathochromic shift $(7 \mathrm{~nm})$ in band II on addition of NaOAc. The existence of a free 5-OH group and a substituted one at position 3 was also evident by the bathochromic shift in a band (I) $(47 \mathrm{~nm})$ on the addition of $\mathrm{AlCl}_{3} / \mathrm{HCl}$. Complete acid hydrolysis yielded isorhamnetin as aglycone and the sugars glucose and rhamnose which were identified by (CO-PC) in ratio $(2: 1)$ with authentic markers. Partial acid hydrolysis gave two intermediates; isorhamnetin-3-O- $\alpha$-Lrhamnopyranosyl $(1 \rightarrow 2)-\beta$-D-glucopyranoside and isorhamnetin-3-O- $\beta$-D-glucopyranoside which were identified through $\mathrm{R}_{\mathrm{f}}-$ values, colour reactions, UV and ${ }^{1} \mathrm{H}-\mathrm{NMR}$ spectral data. Enzymatic hydrolysis of $\left(\mathrm{L}_{2}\right)$ using $\alpha$-rhamnosidase failed to give any intermediate i.e. the rhamnose is not a terminal sugar, while using $\beta$-glucosidase gave the intermediate isorhamnetin-3-O- $\alpha-\mathrm{L}-$ rhamnopyranosyl $(1 \rightarrow 2)-\beta$-D-glucopyranoside which identified as mentioned above. So, from these results the link between the sugar rhamnose and the terminal sugar glucose may be $(1 \rightarrow 2)$.

More evidence of its structure was detected through the negative-ion ESIMS showed a molecular ion peak $[\mathrm{M}-\mathrm{H}]$ at $\mathrm{m} / \mathrm{z} 785,{ }^{1} \mathrm{H}-\mathrm{NMR}$ spectroscopy ensuring the structure of $\left(\mathrm{L}_{2}\right)$ to be isorhamnetin 3-O- $\beta$-D-glucopyranosyl $\left(1^{\prime \prime \prime} \rightarrow 2^{\prime \prime \prime}\right) \quad-\alpha$-L-rhamnopyranosyl $\quad\left(1^{\prime \prime \prime} \rightarrow 2^{\prime \prime}\right)-\beta$-Dglucopyranoside by the appearance of the chemical shifts $\delta(\mathrm{ppm})$ of isorhamnetin skeleton in addition to 3 doublet signals centered at $\delta$ ppm, $5.54(\mathrm{~J}=7.50$ $\mathrm{Hz}), 5.38(\mathrm{~J}=2 \mathrm{~Hz})$ and $4.98(\mathrm{~J}=7.50 \mathrm{~Hz})$ which were of the 3 anomeric protons of one glucoside directly attached to position- 3 of the aglycone, the rhamnosyl which attached to position-2 of the glucose and of the terminal sugar (glucose),respectively. Signals appeared at $\delta 3.07-3.79 \mathrm{ppm}$ were attributed to the other aliphatic protons of the sugars besides the presence of another doublet signal at $\delta 0.87 \mathrm{ppm}$
$(\mathrm{J}=6 \mathrm{~Hz})$ attributed to the methyl group of rhamnose. Finally, $\left(\mathrm{L}_{2}\right)$ structure was proven through ${ }^{13} \mathrm{C}-\mathrm{NMR}$ spectrum including recorded $\mathrm{C}$-signals of the aglycone which have chemical shifts similar to those reported for isorhamnetin [16,17]; besides the appearance of 18 carbon resonances of the three sugar moieties. The carbon signals appeared at $\delta$ 98.2 and 104.3 which assignable of the anomeric carbons of the two glucose and 100.6 anomeric carbon of rhamnose, on the other hand glucosyl C-2" ( $\delta$ 77.5) shifted to lower field showing that rhamnose was attached to 2-position of internal glucose and C-2"' $(\delta$ 81.8) shifted to lower field showing that the external glucose was attached to 2-position of middle rhamnose.

Results of green synthesis of silver nanoparticles

The UV-visible spectra of synthesized silver metal nano particles of Brassica rapa extract (Fig. 2).

The UV-visible spectra show an absorption band at $421 \mathrm{~nm}$ which corresponds to the absorbance of silver nano-particles [18].

(TEM) micrographs of synthesized silver metal nano particles using the Brassica rapa extract at room temperature (Fig. 3).

Transmission electron microscopy (TEM) micrograph of the Silver metal Nano particles (Ag NPs) synthesized using Brassica rapa extract (BRE) is shown in Fig. 3. Transmission electron microscopy (TEM) images of different magnifications reveal that the formations of silver metal nano particles (Ag NPs) are spherical in shape and the particle sizes are in the range 3-20 nm [19].

Fourier Transform Infrared Spectroscopy (FTIR):-

(FTIR) of Brassica rapa extract (Fig. 4):-

(FTIR) of Silver metal nano particles Extract Fig (5):-

The peak at $621 \mathrm{~cm}^{-1}$ in Fig.5 is due to silver metal vibrations [20]. The chelating to the silver metal nanoparticles is a characteristic of flavonoid [21]. All these prominent peaks correspond to flavonoid and protein are present in synthesized Ag NPs. stretching vibrations of phenol/ carboxylic group present in extract. Therefore, it may be inferred that these biomolecules are responsible for capping and efficient stabilization of synthesized nanoparticles.

\section{Results of the antioxidant activity}

As the absorption at $517 \mathrm{~nm}$ decreased, the radical scavenging activity increased. The 




Fig 2. UV-visible spectra of (Ag NPS).


Fig. 3.TEM micrograph of the (Ag NPs).

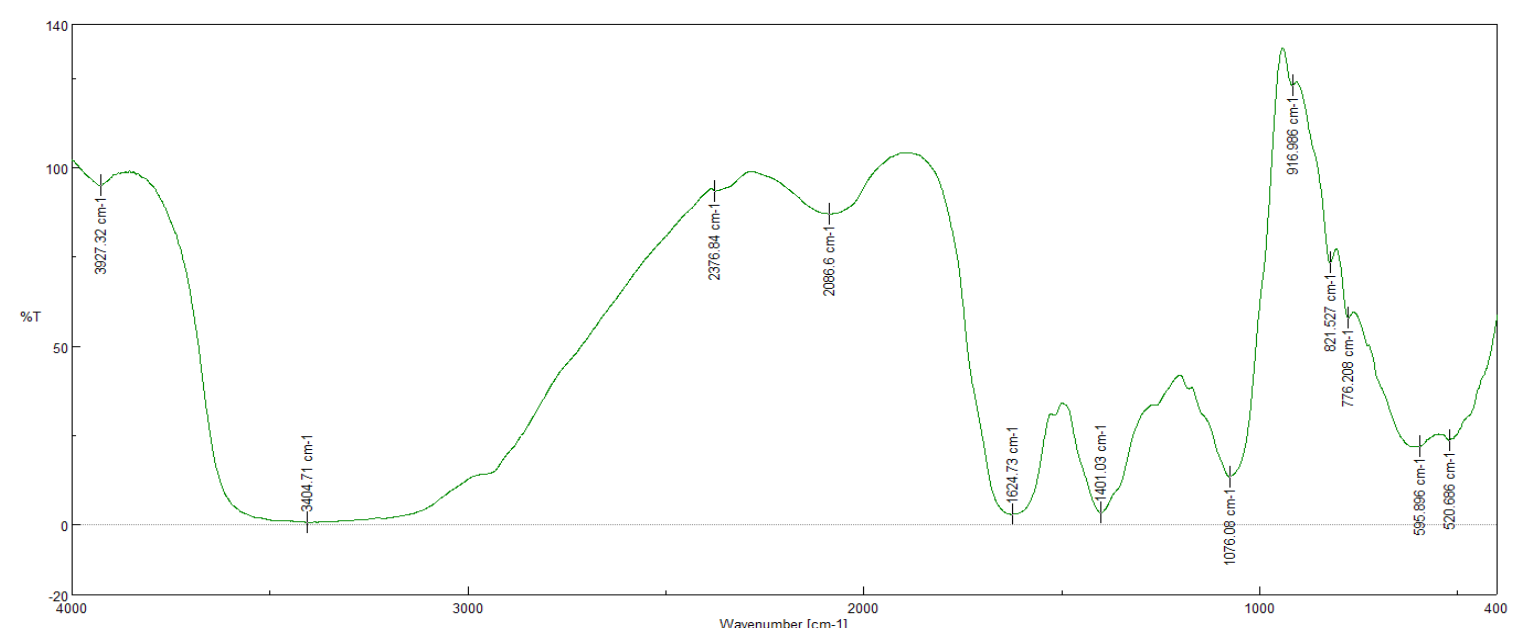

Fig. 4. FTIR OF ( BRE ).

Egypt.J.Chem. 61, No.2 (2018) 




Fig .5. FTIR OF ( NBRE).

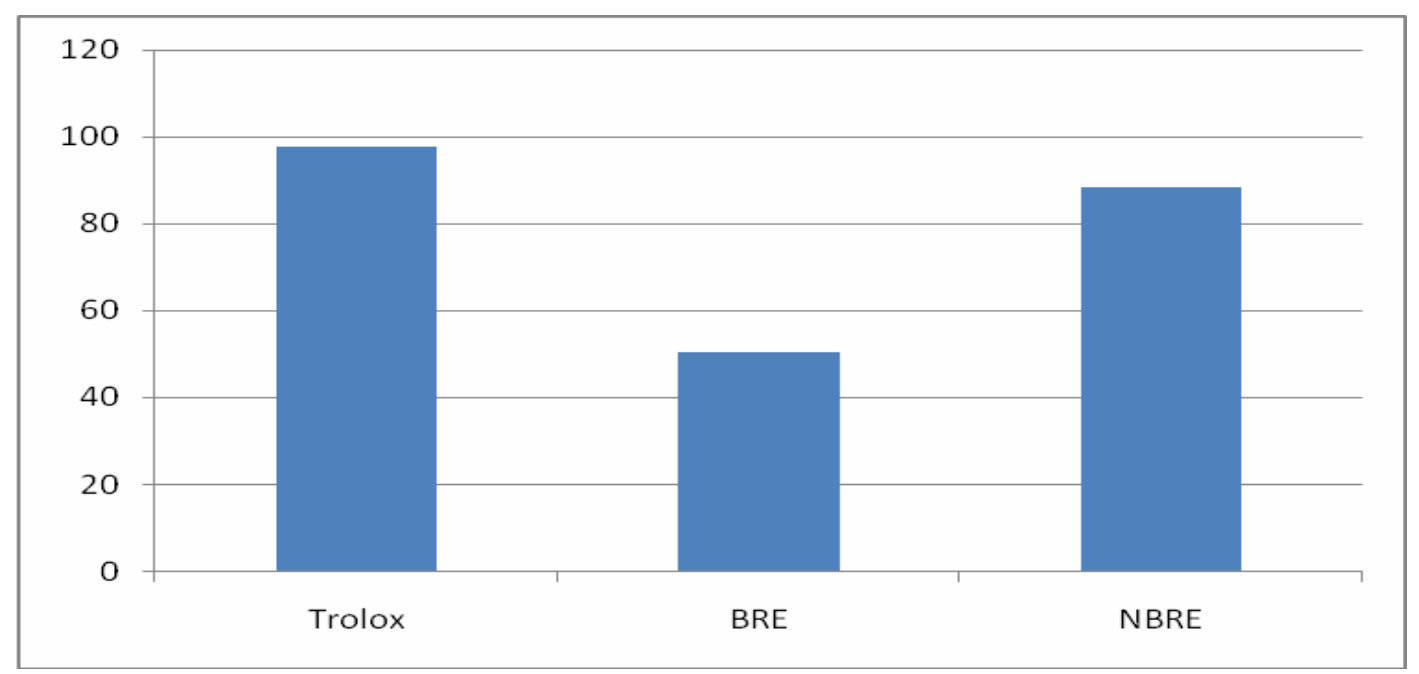

Fig .6. The antioxidant activity of (BRE) and (NBRE).

TABLE 1.The Antioxidant activity.

\begin{tabular}{|l|c|c|}
\hline No. & Sample & \% Inhibition \\
\hline 1 & Trolox & 97.56 \\
\hline 2 & BRE & 50.49 \\
\hline 3 & NBRE & 88.46 \\
\hline
\end{tabular}

antioxidant activity of different extracts (Table 1) showed that, the highest antioxidant extract was Nano particles extract followed by Ethanol fraction ( $88.46 \%, 50.49 \%$ ) which may be due to its containing of phenolic and flavonoidal compounds. Results of the cytotoxic activity

The in vitro anticancer activities of BRE. and its NBRE. were evaluated against HELA cells (human Cervical cancer cell line), M-NFS-60 cells (human Mouse Myelogenous Leukemia carcinoma) with Doxorubicin as standard drug. The drug dose which decreases survival to half $\left(\mathrm{IC}_{50}\right)$ was determined in this study. The results for the two extracts were recorded in Table 2, and shown in Fig. 7,8,9\&10 while that for the standard (Doxorubicin Reference Standard) in Table 3.

\section{Conclusion}

This is the first report of the isolation of the flavonoid compound from Brassica rapa L. , Silver metal nanoparticles were also prepared by Brassica rapa $\mathrm{L}$ extract which gave nanoparticles less than $20 \mathrm{~nm}$. We have measured the antioxidant activity which showed that silver metal nano particles extract have $88 \%$ and Brassica rapa extract $50 \%$ where standard Torolox $97 \%$. The cytotoxic activity of silver metal nano particles and Brassica rapa extract were measured (3.53 $\mu \mathrm{g} / \mathrm{ml}$ and $180 \mu \mathrm{g} / \mathrm{ml}$ ) respectively on (HELA cell line) and $(7.38 \mu \mathrm{g} / \mathrm{ml}$ and $94.4 \mu \mathrm{g} / \mathrm{ml})$ Egypt.J.Chem. 61, No.2 (2018) 
TABLE 2.Cytotoxic activity of the ethanolic extract of Brassica rapa and nano particles extract.

\begin{tabular}{|c|c|c|c|c|}
\hline \multirow[b]{2}{*}{ Samples } & \multicolumn{2}{|c|}{ HELA cell line } & \multicolumn{2}{|c|}{ M-NFS-60 cell line } \\
\hline & $\mathbf{A}$ & B & $\mathbf{A}$ & B \\
\hline Sample conc. $(\mu \mathrm{g} / \mathrm{ml})$ & Viability \% & Viability $\%$ & Viability \% & Viability \% \\
\hline 500 & 21.73 & 3.68 & 12.45 & 4.17 \\
\hline 250 & 36.41 & 5.96 & 23.67 & 7.59 \\
\hline 125 & 60.72 & 9.87 & 34.94 & 13.43 \\
\hline 62.5 & 76.59 & 17.04 & 65.73 & 20.89 \\
\hline 31.25 & 89.14 & 25.35 & 80.98 & 31.23 \\
\hline 15.6 & 96.24 & 31.82 & 91.33 & 40.79 \\
\hline 7.8 & 100 & 40.56 & 98.42 & 48.64 \\
\hline 3.9 & 100 & 47.23 & 100 & 61.35 \\
\hline 2 & 100 & 59.12 & 100 & 72.93 \\
\hline 1 & 100 & 67.88 & 100 & 84.67 \\
\hline 0 & 100 & 100 & 100 & 100 \\
\hline$I C_{50}$ & $I C_{50}=180 \mu \mathrm{g} / \mathrm{ml}$ & $I C_{50=} 3.53 \mu \mathrm{g} / \mathrm{ml}$ & $I C_{50=} 94.4 \mu \mathrm{g} / \mathrm{ml}$ & $I C_{50=} 7.38 \mu \mathrm{g} / \mathrm{ml}$ \\
\hline
\end{tabular}

A-Brassica Rapa extract

B- Silver Nano particles extract

TABLE 3.Cytotoxic activity of the standard drug.

\begin{tabular}{|c|c|c|c|c|c|c|}
\hline \multirow{3}{*}{$\begin{array}{c}\text { Samples } \\
\begin{array}{c}\text { Sample conc. } \\
(\mu \mathrm{g} / \mathrm{ml})\end{array}\end{array}$} & \multicolumn{3}{|c|}{ HELA cell line } & \multicolumn{3}{|c|}{ M-NFS-60 cell line } \\
\hline & \multicolumn{3}{|c|}{ Doxorubicin Reference Standard } & \multicolumn{3}{|c|}{ Doxorubicin Reference Standard } \\
\hline & Viability \% & Inhibition \% & S.D. ( \pm$)$ & $\begin{array}{c}\text { Viability } \\
\%\end{array}$ & $\begin{array}{c}\text { Inhibition } \\
\%\end{array}$ & S.D. ( \pm ) \\
\hline 500 & 2.11 & 97.89 & 0.29 & 1.36 & 98.64 & 0.38 \\
\hline 250 & 4.39 & 95.61 & 0.44 & 3.19 & 96.81 & 0.61 \\
\hline 125 & 6.49 & 93.51 & 0.89 & 5.71 & 94.29 & 0.72 \\
\hline 62.5 & 15.46 & 84.54 & 0.79 & 9.51 & 90.49 & 0.70 \\
\hline 31.25 & 21.11 & 78.89 & 0.37 & 16.83 & 83.17 & 0.92 \\
\hline 15.6 & 27.09 & 72.91 & 0.91 & 24.25 & 75.75 & 0.76 \\
\hline 7.8 & 34.00 & 66.00 & 2.24 & 32.99 & 67.01 & 1.58 \\
\hline 3.9 & 42.90 & 57.10 & 1.65 & 40.97 & 59.03 & 1.28 \\
\hline 2 & 53.23 & 46.77 & 2.44 & 52.25 & 47.75 & 1.07 \\
\hline 1 & 60.37 & 39.63 & 0.99 & 61.74 & 38.26 & 2.06 \\
\hline 0.5 & 69.71 & 30.29 & 1.08 & 69.31 & 30.69 & 0.58 \\
\hline 0.25 & 78.71 & 21.29 & 2.58 & 77.35 & 22.65 & 0.97 \\
\hline 0 & 100 & 0.00 & & 100 & 0.00 & \\
\hline
\end{tabular}




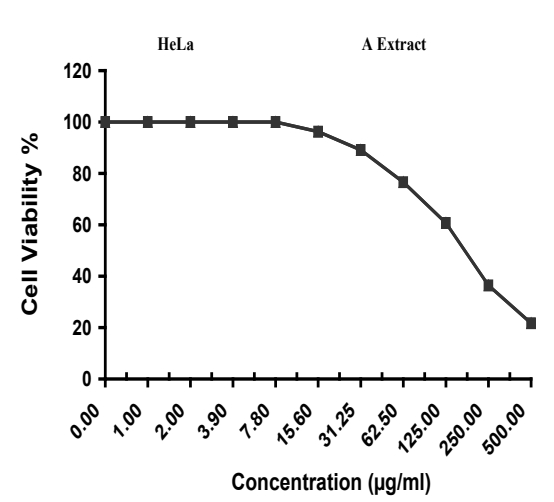

Fig.7.

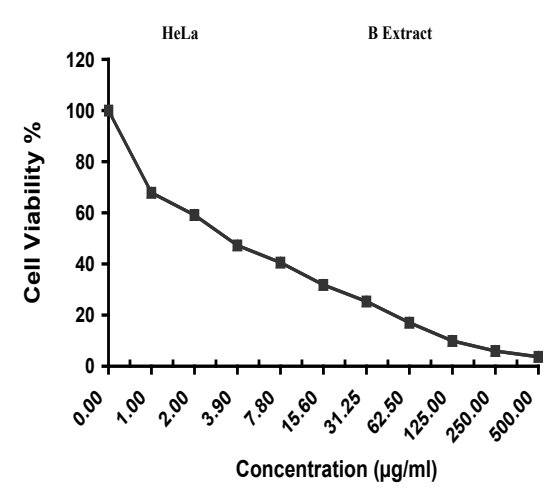

Fig.8.

Fig. 7 and 8. Cytotoxic activity of (BRE) and(NBRE) on (HELA cell line).



Fig.9.

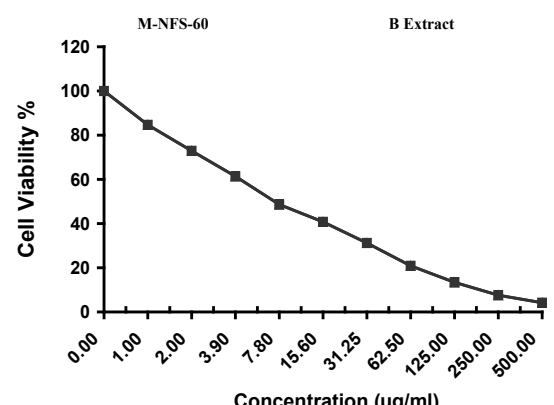

Fig.10.

Fig. 9 and 10. Cytotoxic activity of (BRE) and (NBRE) on (M-NFS-60 cell line).



Fig.11.



Fig.12.

Fig. 11 and 12. Cytotoxic activity of the standard drug Doxorubicin Reference Standard. 
respectively on (M-NFS-60 cell line).

\section{References}

1. Cartea, M. E., Francisco, M., Soengas, P. and Velasco, P., Phenolic Compounds in Brassica Vegetables. Molecules, 16, 251-280 (2011).

2. Beltagy, A. M., Investigation of new antimicrobial and antioxidant activities of Brassica rapa L . International Journal of Pharmacy and Pharmaceutical Sciences , 6, Issue 6 (2014).

3. Ahmadvand, S. and Sariri, R., Antimicrobial Activity of Crude Extracts of Turnip (Brassica rapa). Journal of Pure and Applied Microbiology., 0973-7510 (2008).

4. Fernandes, F., Sousa, C., Pereira J.A., Seabra R.M., Andrade P.B. and Valentão P., Chemical and antioxidative assessment of dietary turnip (Brassica rapaL. Food Chem., 105,1003-10 (2007).

5. Rafatullah, S., Al-Yahya M., Mossa J.,Galal K., Preliminary Phytochemical and Hepatoprotective Studies on Turnip Brassica rapa L. International Journal of Pharmacology, 2(6),670-673 (2006).

6. Daryoush, M., Bahran A., Yousef D., and Mehrdad N., Protective effect of Turnip root Brassica rapaL.ethanolic extract on early hepatic injuryinalloxanized diabetic rats. Australlian J. of Basic and Applied Sciences, 5(7),748-756 (2011).

7. Liu, H., Mou,Y., Zhao J., Flavonoids from Halostachyscaspica and Their Antimicrobial and Antioxidant Activities. Molecules, 15 ,7933-7945 (2010).

8. Ryu, J., Kim D., In, M., Lee S. P., C, J. and and D., Antioxidant potential of ethanol extract of Brassica rapaL. root, Journal of MedicinalPlants Research,6(9),1581-4 (2012).

9. Vallejo, F., Tomas-Barberan, F.A., Ferreres, F., Characterisation of flavonols in broccoli (Brassica oleracea L. var. italica) by liquid chromatographyUV diode-array detection-electrospray ionisation mass spectrometry. J. Chromatogr., 1054, 181-193 (2004).

10. Lin, L.Z.; Harnly, J.M., Phenolic Component Profiles of Mustard Greens, Yu Choy, and 15 Other Brassica Vegetables. J. Agric. Food Chem., 58, 6850-6857 (2010).

11. Mahendra, R., Green Biosynthesis of Nanoparticles; Mechanisms and Applications, CAB International, Oxford,UK (2013).

Egypt.J.Chem. 61, No.2 (2018)
12. Sun, T., Tang, J. and Powers, J.R., Effect of pectolytic enzyme preparations on the phenolic composition and antioxidant activity of asparagusjuice. Journal of Agricultural and Food Chemistry, 53(1), 42-48 (2005).

13. Mosmann, T. Rapid colorimetric assay for cellular growth and survival: application to proliferation and cytotoxicity assays. J. Immunol. Methods, 65, 55-63(1983).

14. Gomha, S.M., Riyadh, S.M., Mahmmoud, E.A. and Elaasser, M.M., Synthesis and Anticancer Activities of Thiazoles, 1,3-Thiazines, and Thiazolidine Using Chitosan-Grafted-Poly(vinylpyridine) as Basic Catalyst. Heterocycles, 91(6),1227-1243 (2015).

15.Markham K.R. Technique of Flavonoid Identification, Academic Press, London, New York, Paris (1982).

16. Agrawal, P. K., Carbon-13 NMR of Flavonoids, Elsevier, Amsterdam. Vol. 39, Oxford, New York and Tokyo (1989).

17. Harborne, J.B., The Flavonoids: Advances in Research Since 1986. Chapman and Hall, London, UK (1993).

18.Vigneshwaran, N., Ashtaputre, N. M., Varadarajan, P. V., Nachane, R. P., Paralikar, K. M. and Balasubramanya, R. H. Biological synthesis of silver nano particles using the fungus Aspergillus flavus. Mater. Lett. 61, 1413-1418 (2007).

19.Vigneshwaran, N., Kathe, A.A., Varadarajan, P.V., Nachane R.P. and Balasubramanya R.H., Biomimetics of silver nano particles by white rot fungus, Phanerochaete chrysosporium. Colloid Surf B., 53,55-59 (2006).

20. Johnson, I. and Prabu, H. J., Green synthesis and characterization of silver nanoparticles by leaf extracts of Cycascircinalis, Ficus amplissima, Commelinabenghalensis and Lippianodiflora.. Int. Nano. Lett. 5, 43-51 (2015).

21. Shankar, S.S., Rai, A., Ahmad, A. and Sastry, M. Rapid synthesis of $\mathrm{Au}, \mathrm{Ag}$ and bimetallic Au coreAg shell nanoparticles using Neem Azadirachtaindica leaf broth. J. Colloid Interface Sci, 275,496502 (2004). accepted 12/2/ 2018) 
دراسات فيتوكيميائيه: مضادات الأكسدة وسميه المركبات لنبات اللفت وجزيئات الفضه الناتومتريه ريهام عزت شفيق عبدالله'، هيلانه نجيب ميشيل'، احمد زكي سيد احمد'، احمد جلال ابراهيم"، احمد مصطفي السيد

احمد' (حسن 'قنم كيمياء المو اد الدابغه وتكنولوجيا الجلود بالمركز القومي للإبحوث ـ القاهرة ـمصر .

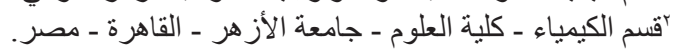



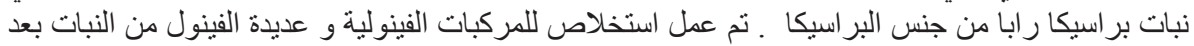

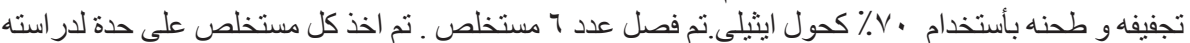

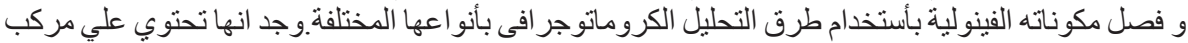


isorhamnetin 3-O- $\beta$-D-glucopyranosyl $(1 \rightarrow 2)-\alpha$-L-rhamnopyranosyl $(1 \rightarrow 2)-\beta-D-$ ) (glucopyranoside

بالاضافه الي 10 مركب تم فصلهم من قبل و هم 0 من نوع كامفيرول جليكوسايد و ؛ من نوع نوع كيرستين

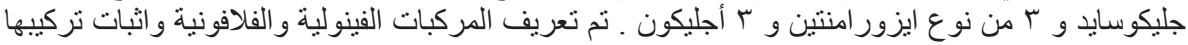

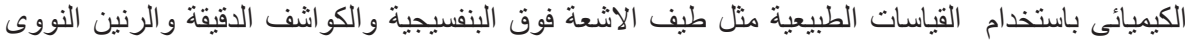

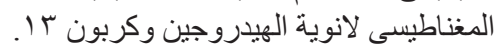



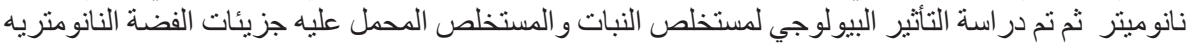

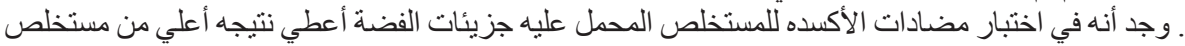
النبات و أيضا نم اختبار سمية الخلايا السرطانيه علي نوعين من الخلايا (سرطان عنق الرحم - سرطان الدام )

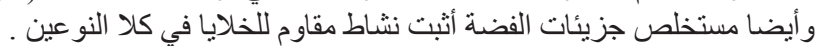

